(2) Open Access Full Text Article

ORIGINAL RESEARCH

\title{
Assessment of the Impact of Sheep and Goat Pox Lesions on Skin Quality in Selected Ware Houses of Central Ethiopia
}

\author{
Ambaye Kenubih (D) \\ Bedaso Mammo ${ }^{2}$ \\ Getachew Terefe ${ }^{2}$ \\ Tewodros Fentahun' \\ 'University of Gondar, College of \\ Veterinary Medicine and Animal Sciences, \\ Gondar, Ethiopia; ${ }^{2}$ Addis Ababa \\ University, College of Veterinary \\ Medicine and Agriculture, Bishoftu, \\ Ethiopia
}

Background: The study was performed from January 2016 to May 2017 with the aim of identifying the impact of sheep and goat pox in skin quality in selected localities of central Ethiopia. Materials and Methods: A total of 1360 fresh, salted and dried skins were examined and graded. Pox lesion positive skins were examined by PCR to identify the agent.

Results: The prevalence of sheep and goat in the study areas was $4.022 \%$. From a total of 86 rejected skins, a large number of skins were in the rejected category $(2.78 \%)$. There were highly statistically significant associations $(\mathrm{p}<0.05)$ between sheep and goat pox and species and study areas. However, there were no statically significant associations $(p>0.05)$ between skin size and sheep and pox. Molecular diagnosis of the case revealed that goat pox virus was responsible for the lesion.

Conclusion: Goat pox virus is the main cause of skin rejection and the factor that causes downgrading of skin.

Keywords: central Ethiopia, sheep and goat pox, skin quality

\section{Introduction}

Ethiopia has a huge livestock population in Africa, possessing more than 56.7 million cattle, 29.3 million sheep, 29.1 million goats, 1.5 million camels, 7 million equines and 52 million chickens. ${ }^{1}$ This makes Ethiopia stand second next to Nigeria, by the number of small ruminants in Africa. ${ }^{2}$ Annually, 16.6 million small ruminant skins are produced in the country, among these $33 \%$ and $32.5 \%$ were obtained from sheep and goats, respectively. ${ }^{3}$ Despite a huge potential of off take rates; the production of high-quality skins was curtailed. ${ }^{4,5}$

Fish, birds, and reptiles, as well as wild and domesticated animals, can provide hides and skins. Cattle, sheep, and goats are the most important sources of hide and skin in Ethiopia. In 1998/99, the potential production is projected to 2.38 million cow hides, 10.07 million sheep skins, and 7.38 million goatskins based on annual off-take rates of $7 \%$ for cattle, $33 \%$ for sheep, and $35 \%$ for goats. This leather industry's raw material is mostly obtained from rural parts of the country where basic facilities for slaughtering and subsequent marketing are either non-existent or non-existent. Hide obtained from cattle, as well as skins obtained from goats and sheep, are country's major items that account for the vast majority of agricultural export commodities followed by live animals. ${ }^{6}$

Sheep and goats play a substantial role in the gross domestic product of the countryto date, the benefits gained from these small ruminants are fraught by
Correspondence: Ambaye Kenubih Email ambayken@yahoo.com 
different constraints. Livestock diseases are amongst the significant practical precincts that have slowed down the progress of the livestock sector by decreasing production and impeding the trade of live animal and animal products. ${ }^{7,8}$ Among these infectious diseases, sheep and goat pox are the main problem and widely spread diseases in all regions of Ethiopia. ${ }^{2}$

More than $35 \%$ of sheep and $56 \%$ of goat skins have downgraded and rejected due to pre- and post-slaughter defects. The majority of defects are caused by pre- and post-slaughter defects due to skin diseases and poor because of various antemortem and postmortem defects caused by poor animal husbandry and nutrition, skin diseases and parasites, improper slaughter and flaying operations and improper practices of curing, collection, transportation and storage. ${ }^{9}$ Tanneries state that only $10 \%$ to $15 \%$ of harvested skins qualify for top grades, with the rest downgraded and rejected mainly due to deterioration of skin quality owing to skin diseases and various defects. ${ }^{10}$ Sheep and goat pox is among the disease which is responsible for deterioration of the quality of skin.

Sheep and goat pox virus (SGPV) is highly contagious viral disease of sheep and goats, in the genus Capripox virus (CaPV), subfamily Chordopoxvirinae, and family Poxviridae. ${ }^{11}$ The sheep pox virus (SPPV), goat pox virus (GTPV), and lumpy skin disease virus (LSDV) showed 96\% nucleotide and amino acid similarity over their entire length. ${ }^{12}$ The central genomic region surrounded by two identical inverted terminal repeats (ITR) at the ends of SGPV (ORFs 024 to 123) comprises homologues of conserved genes involved in basic replication systems as well as in viral DNA replication, transcription, RNA modification, and structure and assembly of intracellular mature and extracellular enveloped virions. ${ }^{12-14}$ While the terminal open reading frame (ORF) (001 to 023 and 124 to156) contain genes involving with virulence, host immune evasion and host range functions. ${ }^{12}$ Mature virion cell attachment (P32) comprises the main antigenic determinants which are important for the pathogenicity and diagnosis of the virus. ${ }^{15}$

In endemic areas losses due to SGP include the direct loss; mortality, and the indirect losses include reduced milk yield, weight loss, increased abortion rates, damage to skin, and increased susceptibility to pneumonia and fly strike. $^{16}$

The effect of SGPV on the skin is very high. Lesions developed secondary to virus invasion of the epithelium, ischemic necrosis produced by vascular damage and stimulates the host cell DNA replication which causes epidermal hyperplasia. ${ }^{17}$ The epidermis shows hydropic degeneration and ruptured vesicles at some places exposing the dermis. ${ }^{18}$ Edema, fibroblast proliferation, and accumulation of cellular exudates in the stained section of the dermis. ${ }^{19}$ Extravasations of erythrocytes and coagulative necrosis with effusion of inflammatory cells intermixed with tissue debris was noticed in the hypodermis. ${ }^{18}$ The impact of these pathogenesis mechanisms of the virus may also affect the tannery industry in countries like Ethiopia where leather is the largest source of foreign currency. Now days, the current foreign trade revenue of hide and skin has dropped by $9-10 \%$ on domestic and export markets. ${ }^{20}$ In Ethiopia, it is projected that a higher proportion of skin defects are developed ante-mortem. ${ }^{5,21}$ Among infectious diseases, sheep and goat pox are the major trait for the small ruminant sector and the second largest cause of skin rejection next to parasitic causes. ${ }^{22}$ Skin grades on skin collected from different areas of Ethiopia showed that greater than $85 \%$ hide was rejected due to pox and less than $6 \%$ was graded $1-4 .^{22}$ The main aim of this research is to assess the impact of SGP in warehouses and the quality impacts of SGP on skin in ware houses.

\section{Materials and Methods}

\section{Study Area}

The research was conducted in West Shewa, East and west Arsi. Arsi Negele is located in the west Arsi zone of Oromia regional state. Arsi Negele is located at a longitude of $7^{\circ} 21^{\prime} \mathrm{N}$ and latitude of $38^{\circ} 42^{\prime} \mathrm{E}$ and 2043 meters above sea level. Ziway is located at the longitude of $7^{\circ} 56^{\prime} \mathrm{N}$ and latitude of $38^{\circ} 43^{\prime} \mathrm{E}$ and 1636 meters above sea level. Dhera is located $30 \mathrm{Km}$ away from Adama on the highway connecting Adama to Assela. Dhera is located at the longitude of $8^{\circ} 15^{\prime} \mathrm{N}$ and latitude of $39^{\circ} 20^{\prime} \mathrm{E}$ and 2430 meters above sea level ${ }^{1}$ (CSA, 2015). These areas receive bimodal rainfall and local farmers practice rain feed agriculture and also practice irrigation.

\section{Sample Size}

A cluster sampling method was applied to identify skin defects from skins collected from three districts. Sample size was estimated according to Thrusfield, ${ }^{23}$ the sample size was 384 where an expected prevalence of $50 \%$ is to be estimated with a desired absolute precision of $\pm 5 \%$. To 
maximize the accuracy of the data produced by the survey, we sampled more than the average.

\section{Study Design}

Three (each with a potential of collecting $>5000$ skins per annum) private skin collection shades/stores were purposively selected based on proximity to the transport access. Twenty percent of the warehouses' sheep and goat skins (fresh, salted or air-dried skins) were selected using a simple random sampling method. Complete physical examination was performed on randomly selected skins and data were recorded to generate information related to sheep and goat pox like; distribution of the lesion, lesion type, size, and skin grade. The skin was categorized by size, preservation methods (fresh, salted, and air dried) and skin defects caused by sheep and goat pox. ${ }^{24}$ Skin inspection was made by day light to check for any defects.

\section{Laboratory Examination}

Skin biopsies for virus genome detection were collected from skin lesions and placed in a sterile screw-capped test tubes and placed immediately on an icebox and then in $20^{\circ} \mathrm{C}$ and sent to the department of Molecular biology in National Veterinary Institute (NVI), Ethiopia, for molecular diagnosis. ${ }^{25}$ Skin tissues were rinsed with phosphate buffered saline 3 times. Skin tissues were analyzed, minced with a sterile scissor and crushed with a sterile pestle and mortar as described by Mangana-Vougiouka et al. ${ }^{26,27}$ The viral genomic DNA extraction was done using the QIAamp DNA Mini Kit (QIAGEN, Hilden, Germany) using the manufacturer's instructions as a base and finally the DNA was eluted using $50 \mu \mathrm{L}$ elution buffer. The PCR was conducted using RNA polymerase $30 \mathrm{KDa}$ (RPO30) primers: Forward primer 5' TCTATGTTCTTGA TATGTGGTGGTAG $3^{\prime}$ and Reverse primer 5' AGtGAtTAGGtGgtgtattatTTtCC 3'. Polymerase chain reaction $(\mathrm{PCR})$ was carried out in a $25 \mu \mathrm{L}$ reaction volume in a $200 \mu \mathrm{L}$ capacity PCR tube containing 12.5 $\mu$ LMaxima Hot Start Green PCR Master Mix (QIAGEN, Hilden, Germany), $0.5 \mu \mathrm{L}$ of each primer $(10 \mathrm{pmol} / \mu \mathrm{L}), 1 \mu \mathrm{L}$ of extracted DNA and $10.5 \mu \mathrm{L}$ of nuclease free water. The amplification was performed according to Lamien et $\mathrm{al}^{28}$ in a thermocycler (Eppendorf $\mathrm{AG}$, Hamburg, Germany) adjusted as denaturation $\left(95^{\circ} \mathrm{C}\right.$ for 4 $\min )$, followed by 35 cycles of denaturation $\left(95^{\circ} \mathrm{C}\right.$ for 30 sec), annealing $\left(55^{\circ} \mathrm{C}\right.$ for $\left.30 \mathrm{sec}\right)$ and extension $\left(72^{\circ} \mathrm{C}\right.$ for $30 \mathrm{sec}$ ) and final extension $\left(72^{\circ} \mathrm{C}\right.$ for $\left.5 \mathrm{~min}\right)$. Three percent ultrapure, electrophoresis grade agarose gel containing
$1 \mu \mathrm{g} / \mathrm{mL}$ Ethidium Bromide in TAE buffer, was prepared and casted in a mold. When the gel was completely solidified, the combs was removed carefully and the gel was placed in the electrophoresis tank containing $1 \mathrm{X}$ TAE running buffer before loading the samples. In the centre of the first well, $5 \mu \mathrm{L}$ of $100 \mathrm{bp}$ DNA ladder was loaded, while in the remaining wells, $6 \mu \mathrm{L}$ of sample DNA with $2 \mu \mathrm{L}$ of DNA loading dye (50\% glycerol, $6 \mathrm{x}$ TAE, $1 \%$ bromophenol blue) was loaded by using micropipettes. After electrophoresis on 3\% agarose gel (1hr at $100 \mathrm{~V})$ the PCR product was visualized on a UV Transilluminator (UVtec, Cambridge, UK).

\section{Data Analysis}

The data was collected by a pretested questionnaire and filled in a spread sheet Excel analysis was by using SPSS version 24 (SPSS. Inc.) and a significant association between variables was said to exist if the computed P-value is $\leq 0.05$. Student's $t$-test was applied to see the difference between species, preservatives used and study area.

\section{Results}

A total of 2014 skins (998 sheep skin and 1016 goat skin) were examined during the study period (Table 1). The prevalence of SGP in warehouse was $4.02 \%(n=81)$. The vast majority of the SPG lesions were scars $(n=45)$, followed by nodules and papule $(n=19)$ and $(n=13)$, respectively. According to Ethiopian Standard Authority (ESA, 2012), only a small proportion of shoat skins drop in the extra small $(1 \%)$, very small $(11.56 \%)$, and extralarge category $(0.145 \%)$. Large proportion of shoat skin were categorized under the small (21.6\%), medium (31.1\%), large $(25.76 \%)$, and very large $(8.6 \%)$ categories.

Despite a large number of SGP, positive skins fall in small, medium, and large categories; there was no substantial variance between different sizes and SGP (P.0.05) as shown in table. However, there was a significant difference between species $(\chi 2=8.314 ; \mathrm{P}=0.016)$ and study area $(\chi 2=53.647 ; \mathrm{P}=0.000)$.

As depicted in Table 2 SGP was responsible for an epic downgrading of skin $(n=27,1.3 \%$ fall in grade 5$)$ and rejection of skin $(n=21,1 \%)$, and usually a large proportion of the affected skin fall in grades 4, 5, 6 and reject category. Among rejected skins $(n=79), 25 \%$ was due to SGP (Table 2). Furthermore, there is a strong correlation and association between skin down grading and SGP $(\mathrm{P}<0.05)$.

All samples, whether it was collected from sheep or goat, were given a 172 bp sized DNA product during RPO30 gene 
Table I The Distribution of SGP in Terms of Spp., Size, Study Area, Preservation and Lesion Types

\begin{tabular}{|l|l|l|l|l|l|}
\hline Variables & Classes & N & SGP & $\mathbf{X}^{2}$ & P value \\
\hline Species & Ovine & 1016 & 49 & 8.314 & 0.016 \\
& Caprine & 998 & 32 & & \\
\hline Size & Extra-Small & 22 & 0 & 11.525 & 0.485 \\
& Very Small & 233 & 8 & & \\
& Small & 436 & 17 & & \\
& Medium & 627 & 26 & & \\
& Large & 519 & 23 & & \\
& Very Large & 174 & 4 & & \\
& Extra-Large & 3 & 0 & & \\
\hline \multirow{5}{*}{ Study Area } & A. Negele & 804 & 2 & 53.647 & 0.000 \\
& Ziway & 700 & 53 & & \\
& Dhera & 510 & 26 & & \\
\hline \multirow{5}{*}{ Preservation } & Fresh & 832 & 46 & 12.271 & 0.015 \\
& Dry & 110 & 1 & & \\
& Salted & 1072 & 34 & & \\
\hline \multirow{5}{*}{ Viral Lesion } & Macule & 12 & 12 & 2067.723 & 0.000 \\
& Nodule & 19 & 19 & & \\
& Papule & 13 & 5 & & \\
& Scar & 45 & 45 & & \\
\hline
\end{tabular}

Note: $n=2014$.

amplification. All samples, whether it was collected from sheep or goat, were given a $172 \mathrm{bp}$ sized DNA product during RPO30 gene amplification. RPO30 gene of SPPV has $151 \mathrm{bp}$ size while the GTPV and LSDV have 172bp size.

\section{Discussion}

A lot of works done on skin quality fail to describe problems that can downgrade skin quality infectious diseases like sheep and goat pox (SGP). This study discloses the most significant aspects of SGP in the quality of skin in warehouses. ${ }^{29}$ Epithelial regeneration from the underneath of the scab takes several weeks. The disease causes irreversible damage to the skin and a star-shaped, hairless or wool less scar is formed. The scar affects the grain side of the skin. ${ }^{30}$

The total prevalence of SGP in warehouses in this study was $4.02 \% ; 2.28 \%$ and $1.69 \%$ of the pox lesion was observed on fresh skin and salted skin, respectively. Our finding is in line with other findings. ${ }^{21,31}$ Kahsay et $\mathrm{al}^{21}$ documented that the prevalence of SGP in salted skin and dry skin was $15 \%$ and $6.8 \%$, respectively. While Tsigab et al ${ }^{31}$ reported that the prevalence of pox lesion was $3.6 \%$ and $4 \%$ in dry skin and wet skin, respectively. Pox lesions were observed more often on wet blue goat skins $(10.8 \%)$ and wet blue hides $(8.1 \%)$ than in pickled sheep skins $(1.2 \%){ }^{21}$

In Tannery-based studies conducted in Bahirdar tannery and Modjo export tannery, the prevalence of SGP was $10 \%{ }^{32}$ and $9.5 \%{ }^{33}$ Usually, the prevalence of SGP lesions in tanneries is by far larger than that of warehouses. After the tanning process, fully recovered lesions become more protuberant in the form of white spots on the skin and usually confusing Cokkel scars. ${ }^{30}$

In Ethiopia, very limited work has been done on sheep and goat pox virus but some researches have been made on participatory disease surveillance (PDS) in selected districts of Afar region and Northeastern part of Ethiopia and central Ethiopia Gari et $\mathrm{al}^{34}$ and seroprevalence and distribution of sheep and goat pox virus in Northwest Amhara region Ethiopia were reported by Fentie et al. ${ }^{2}$ Furthermore, isolation and characterization of poxvirus was done by Demena ${ }^{35}$ in west Shoa and central Ethiopia. A report on epidemiology and economic importance of sheep and goat pox is highly distributed in all regions of Ethiopia and economically important due to production loss and mortality. ${ }^{8,2}$

According to Assefa et al, ${ }^{32}$ large and very large skins are highly affected and $90 \%$ of the affected skin classified in the reject category. However, in our study, a substantial number of skin fell in grade 2, 4, and rejected category (69.13\%). A study conducted in Punjab, Pakistan, old

Table 2 The Impact of SGP on the Total Grade of the Skin

\begin{tabular}{|l|l|l|l|l|l|}
\hline Grand Grade & $\mathbf{n}$ & Percentage & SGP & Percentage of SGP (n=20 I 4) & Proportion of SGP for Downgrade (\%) \\
\hline $\mathrm{I}$ & 402 & 19.95 & - & - & - \\
2 & 512 & 25.53 & 15 & 0.7 & 2.93 \\
3 & 652 & 32.518 & - & - & - \\
4 & 268 & 13.5 & 10 & 0.5 & 3.7 \\
$5^{*}$ & 95 & 4.7 & 27 & 1.3 & 28.4 \\
$6^{*}$ & 17 & 0.8 & 8 & 0.4 & 47.05 \\
Rejected at the warehouse* & 79 & 3.9 & 21 & 1.0 & 26.58 \\
Total & 2014 & 100 & 81 & & \\
\hline
\end{tabular}

Note: *Rejected skin classes. ${ }^{24}$ 
lesions of pox are the second largest skin and hide problem followed by skin atrophy. ${ }^{19}$ However, in our study, the proportion of SGP was $4.02 \%$. Pox accounted for $1.5 \%$, $15.5 \%, 6.8 \%$ and $8.3 \%$ of pickled sheep skins, wet blue or salted goat skins, wet blue or dry goat skins and wet blue hides, respectively, being rejected. ${ }^{21}$

Sheep and goat pox (SGP) is a highly transmissible viral disease that results in an extensive loss in the production and productivity of small ruminants in Ethiopia. Regarding the status of the disease in Ethiopia, SGP was endemic in almost all the regions of Ethiopia. ${ }^{34,35}$ In Ethiopia, a total of 57,638 small ruminants contracted the disease and more than 4.8 million of them were at risk in areas where outbreaks occurred. Out of the 57,638 sick small ruminants, 6,401 animals died with a case fatality rate of $11.11 \%$. Only about $35-40 \%$ the disease was reported in Ethiopia; the actual figures in terms of affected, vaccinated and dead animals are expected to be higher than the reported numbers. Although there were no detailed studies on the prevalence of SGP in Ethiopia, some reports indicate that it is one of the widely distributed and it is the common problem in small ruminant sector of Ethiopia. ${ }^{37}$

The percentage of SGP was $10.34 \%$ and $12.88 \%$ in sheep and goats, respectively, in Adama town, Oromia Regional State. $^{34}$ According to Woldemeskel and Marsha, ${ }^{38}$ the prevalence of pox was $22 \%$ in sheep and $18 \%$ in goats in Wollo, Northeast Ethiopia. The seroprevalence between sheep and goat pox was $17 \%$ and $15.5 \%$, respectively, in Northwest Amhara Region. ${ }^{2}$ According to Teshome, ${ }^{39}$ the prevalence was $40 \%$ in sheep and $8.12 \%$ in goats in Gondar University veterinary clinic. According to Molla et $\mathrm{al}^{40}{ }^{40}$ the prevalence was $31.96 \%$ in sheep and $35.28 \%$ in goats in Gamo Gofa zone of SNNRP. According to Kebede et al, the overall prevalence of small ruminant pox was $11.23 \%$, out of which $12.9 \%$ were goats and $9.5 \%$ were sheep. The prevalence of sheep and goat pox in the country as well in the study area is pretty high; that is why the overall prevalence of pox lesions in the warehouse. Wounds and scars resulting from pox or tick infestations are the common pre-slaughter defects seen in pickled skins, and wet blue skins next to scratches, cockle, poor substance, and brandings. ${ }^{21}$

\section{Conclusion}

In this study, SGP was an important economical disease in the small ruminant sector as well as in the tanning sector. It causes a considerable loss due to decrement in skin grade. The percent loss in warehouses was very high.

\section{Data Sharing Statement}

All the data is contained in the manuscript.

\section{Ethics}

Our study population is inanimate object (skin already collected from slaughtered sheep and goat for food purpose). The research did not include any live animal or questionnaire survey. Because of this reason, the manuscript is exempt from presenting a review by an institutional review board or ethical committee.

\section{Consent for Publication}

All authors read and approved the final manuscript.

\section{Disclosure}

The authors report no conflicts of interest for this work and declare that there is no direct or indirect conflict of interest which may call into question the validity of this study.

\section{References}

1. CSA (Central Statistics Agency). Agricultural sample survey, report on livestock and livestock characteristics; 2015.

2. Fentie T, Fenta N, Leta S, Molla W, Ayele B, Teshome Y. Seroprevalence, risk factors and distribution of sheep and goat pox in Amhara Region, Ethiopia. BMC Vet Res. 2017;13:1-8. doi:10.1186/ s12917-017-1312-0

3. Tadesse H. Pre-slaughter defects of hides/skin and intervention options in East Africa: harnessing the leather industry to benefit the poor. Proceeding of Regional Workshop. Addis Ababa, Ethiopia; 2005:19-30.

4. Ayele S, Assegid W, Jabbar MA, Ahmed MM, Belachew H. Livestock marketing in Ethiopia: a review of structure, performance and development initiatives, working paper. Addis Ababa, Ethiopia; 2003.

5. Kassa B. Pre-slaughter defects of hides/skin and intervention options in East Africa: harnessing the leather industry to benefit the poor. Proceeding of Regional Workshop. Addis Ababa, Ethiopia; 2005:71-84.

6. Food and Agriculture Organization. World statistical compendium for hides, skins, leather and leather footwear tropical and horticultural products service commodities and trade division (ESC) and Food and Agriculture Organization (FAO). United Nations, Rome; 2010. Available from: http://www.fao.org. Accessed July 30, 2021.

7. Jilo K, Abdela N, Adem A. Insufficient veterinary services as a major constraints in pastoral area of Ethiopia: a review. $J$ Biol Agric Healthc. 2016;6:94-101.

8. Yune N, Abdela N. Epidemiology and economic importance of sheep and goat pox: a review on past and current aspects. School of Veterinary Medicine, College of Agriculture and Veterinary Medicine, Jimma University, Jimma. $J$ Vet Sci Technol. 2017;8:2157-7579. doi:10.4172/2157-7579.1000430

9. Adem M. Production of hide and skin in Ethiopia; marketing opportunities and constraints: a review paper. Cogent Food Agric. 2019;5 (1):1565078. doi:10.1080/23311932.2019.1565078

10. Amde B. Major factors affecting hide and skin production, quality and the tanning industry in Ethiopia. Adv Biol Res. 2017;11 (3):116-125. doi:10.5829/idosi.abr.2017.116.125 
11. Bowden TR, Coupar BE, Babiuk SL, et al. Detection of antibodies specific for sheeppox and goatpox viruses using recombinant capripoxvirus antigens in an indirect enzyme-linked immunosorbent assay. J Virol Methods. 2009;161:19-29. doi:10.1016/j.jviromet.2009.04.031

12. Tulman ER, Afonso CL, Lu Z, et al. The genomes of sheeppox and goatpox viruses. $J$ Virol. 2002;76:6054-6061. doi:10.1128/ JVI.76.12.6054

13. Tulman ER, Afonso CL, Lu Z, Zsak L, Kutish GF, Rock DL. Genome of lumpy skin disease virus. $J$ Virol. 2001;75 (15):7122-7130. doi:10.1128/JVI.75.15.7122

14. Pham TH, Yasmin N, Rahaman A, et al. Molecular phylogenetics of a recently isolated goat pox virus from Vietnam. BMC Vet Res. 2021;17:1-11. doi:10.1186/s12917-021-02777-1

15. Gu S, Shi X, Liu X, Wang Z, Zheng M, Li Y. Identification and phylogenetic analysis of the sheep pox virus Shanxi isolate. Biomed Res. 2018;29(3):523-529.

16. Yeruham I, Yadin H, Van HM, Bumbarov V, Soham A, Perl S. Economic and epidemiological aspects of an outbreak of sheeppox in a dairy sheep flock. Vet Rec. 2007;160:236.

17. McGavin MD, Zachary JF. Pathological Basis of Veterinary Diseases. 4th ed. Mosby, Elsiever; 2007.

18. Sajid A, Chaudhary ZI, Maqbol A, et al. Comparative sensitivity of PCR and cell culture technique for the identification of goat pox virus. J Anim Plant Sci. 2013;23(1):31-34.

19. Zangana IK, Abdullah MA. Epidemiological, clinical and histopathological studies of lamb and kid pox in Duhok, Iraq. Bulg J Vet Med. 2013;16:133-138.

20. Grumiller J. A strategic-relational approach to analyzing industrial policy regimes within global production networks: the Ethiopian Leather and Leather Products Sector. Vienna: Austrian Foundation for Development Research (ÖFSE); 2019.

21. Kahsay T, Negash G, Hagos Y, Hadush B. Pre-slaughter, slaughter and postslaughter defects of skins and hides at the Sheba Tannery and Leather Industry, Tigray region, northern Ethiopia. Onderstepoort $J$ Vet Res. 2015;82(1):1-7. doi:10.4102/ojvr.v82i1.931

22. Birhanu W, Negussie H, Alemu S, Mazengia H. Assessment of major factors that cause skin rejection at Modjo export tannery, Ethiopia. Trop Anim Heal Prod. 2011;43:989-993. doi:10.1007/s11250-0119796-2

23. Thrusfield M, Christley R, Helen Brown PJ, et al. Veterinary Epidemiology. 4th. John Wiley \& Sons Ltd; 2018. doi:10.1002/ 9781118280249

24. ESA (Ethiopian Standard Authority). Raw goat skins: part 1-4: guidelines for grading; 2012.

25. OIE. Sheep pox and goat pox terrestrial manual; 2017.

26. Mangana-Vougiouka O, Markoulatos P, Koptopoulos G, Nomikou K, Bakandritsos NA, Papadopoulos O. Sheep poxvirus identification by PCR in cell cultures. J Virol Method. 1999;77:75-79. doi:10.1016/ S0166-0934(98)00138-4

27. Mangana-Vougiouka O, Markoulatos P, Koptopoulos G, Nomikou K, Bakandritsos N, Papadopoulos P. Sheep poxvirus identification from clinical 72 specimens by PCR, cell culture, immunofluorescence and agar gel immunoprecipitation assay. Mol Cell Probes. 2000;14:305-310. doi:10.1006/mcpr.2000.0319
28. Lamien CE, Le Goff C, Silber R, et al. Use of the Capripoxvirus homologue of vaccinia virus $30 \mathrm{kDa}$ RNA polymerase subunit (RPO30) gene as a novel diagnostic and genotyping target: development of a classical PCR method to differentiate goat poxvirus from sheep poxvirus. Vet Microbiol. 2011;21:30-39. doi:10.1016/j. vetmic.2010.09.038

29. Zembaba T, Mengesha D, Negash T, Melaku S, Garedew L. Stereotyping of defects and grading of raw sheep and goat skins collected and stored by skin traders in Bahir-Dar Town, Ethiopia. Int J Anim Vet Adv. 2013;5(1):15-20. doi:10.19026/ijava.5.5572

30. Chaudhary ZI, Saiddain A, Sabir N, Malik NA, Azeem S, Sajid A. Prevalence of pathological conditions causing skin damage and consequently reducing its market value in domestic ruminants of Punjab, Pakistan. Vet Sci Dev. 2011;1:e4. doi:10.4081/vsd.2011.e4

31. Tsigab T, Bsrat A, Alemayohu R, Arefe MA, Hadush B. Effects of skin and hide defects on quality grades and physical characteristics of crust leather. Ethiop Vet J. 2020;24(2):35-53.

32. Assefa M, Tesfaye D, Taye M. A study on the prevalence of sheep and goat skin defects in Bahir Dar tannery, Ethiopia. Online J Anim Feed Res. 2011;2(4):384-387.

33. Urgessa BG. Investigation of major factors that cause skin and hide rejection in Ethiopia: the case of Tanneries in Addis Ababa and Modjo Towns. J Africa Leather Leather Prod Adv. 2014;1 (1):35-44. doi:10.15677/jallpa.2014.v1i1.7

34. Gari G, Mekonen G, Sibhat D, Abebe A, Sahle M, Abie G. Participatory Disease surveillance (PDS) of sheep and goat disease in selected district of Afar regional state particular focus on Pestes des petits ruminants (PPR) and sheep and goat pox disease (SGP). Ethiop Vet J. 2015;19(1):83-105. doi:10.4314/evj.v19i1.8

35. Damena A. Outbreak investigation, isolation and molecular characterization of sheep and goat pox virus in central Ethiopia. 2018.

36. Bhanuprakash V, Indrani BK, Hosamani M. The current status of sheep pox disease. Comp Immunol Microbiol Infect Dis. 2006;29:27-60. doi:10.1016/j.cimid.2005.12.001

37. Weldemeskel MM, Mersha G. Study on caprine and ovine dermatophilosis in Wollo, North east Ethiopia. Trop Anim Prod. 2009;42:41-44. doi:10.1007/s11250-009-9383-y

38. Teshome D. Prevalence of major skin diseases in ruminants and its associated risk factors at University of Gondar Veterinary Clinic, North West Ethiopia. Austin J Vet Sci Anim Husbond. 2016;3:10-19.

39. Molla B, Haile H, Alemu S. Prevalence and risk factors associated to skin diseases in small ruminants in Gamo Gofa zone, Southwestern Ethiopia. J Vet Med Anim Heal. 2017;9(8):228-234.

40. Kebede A, Hailemariam E, Dugassa J. Prevalence of common skin diseases of small ruminants in Dibate district Metekel Zone Beneshangul Gumuz Regional State Northwestern Ethiopia. Sci Ric Open Access Dir. 2018;2:2-3.
Veterinary Medicine: Research and Reports is an international, peerreviewed, open access journal publishing original research, case reports, editorials, reviews and commentaries on all areas of veterinary medicine. The manuscript management system is completely online and includes a very quick and fair peer-review system. Visit http://www.dovepress.com/testimonials.php to read real quotes from published authors. 